\title{
胸䯣症を疑わせた頚椎疾患の検討
}

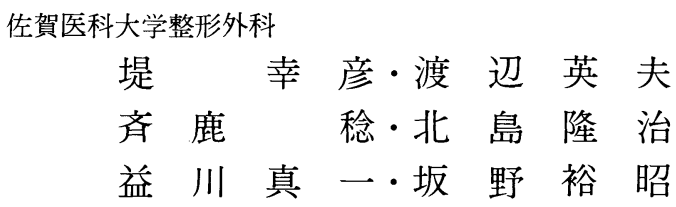

\section{Study of Two Cases of Cervical Disease, Showing Similar Symptoms to Thoracic Myelopathy}

by

Yukihiko Tsutsumi, Hideo Watanabe,

Minoru Saika, Ryuuji Kitajima, Sinichi Masukawa and Hiroaki Sakano

Department of Orthopedics Surgery,

Saga Medical School

In this report, two cases of cervical disease are discussed which showed similar symptoms to thoracic myelopathy based on their neurological signs recognized mainly in the lower limbs and trunk.

Case 1 is a 46 year-old male. He had numbness of the left lower limb and left side of trunk at onset, which gradually increased. However he had no motor disturbance of the extremities.

Case 2 is a 38 year-old female. She had numbness, pain and muscular weakness of the right lower limb at onset, which gradually increased and was accompanied by slight motor weakness of the both lower limbs. Deep tendon reflexes of the lower limbs were hyperactive in both cases. A sensory disturbance was noticed below the level of Th6 in case 1 and below the level of Th4 in case 2. A spastic gait was recognized in case 2.

No sensory or motor disturbance in the upper limbs, except positive Wartenberg's reflex in the both hands, was recognized in case 1 .

Deep tendon reflexes of the upper limbs were slightly hyperactive and Wartenberg's reflex was positive in case 2 .

After studies of myelography, CTM and MRI, the diagnosis of case 1 was cervical spondylotic myelopathy and case 2 was Arnold-Chiari malformation.

䅡椎症は，多彩な神経症状を呈することはよく知ら れているが，主として上肢に初発することが多く，片 側の体幹および下肢に主症状が限局する場合，むしろ 胸髄症が疑われることが多い.

今回, 片側の体幹および下肢の知覚障害を主症状と して発症した頚椎疾患の 2 症例を経験したので, 症例 およびその病態について若干の考察を加えて報告する.

\section{1. 症例及びその経過}

症例 $1 ：$ 46才男性

主訴：左下肢〜腹部にかけてのじんじん感.
現病歴：昭和62年11月頃より特に誘因無く左足底部 より足背にかけじんじん感出現し, 徐々に上昇, 昭和 62年12月には左肋骨下部にまで達し，同時期に下肢の 左右の温度感覚の違いにも気ついている. 昭和63年 1 月 13日, 精查目的にて当科入院した.

既往歴：昭和 44 年, 昭和 56 年に交通事故後に頚部痛 を自覚しているが, 特に治療は受けていない.

家族歴：特記すべき事なし。

入院時理学的所見：頝椎部で左側屈制限, 左傍背柱 筋に圧痛を認めたが, 両上肢には明らかな知党, 運動 障害は認められなかった，左体幹より左下肢にかけて 


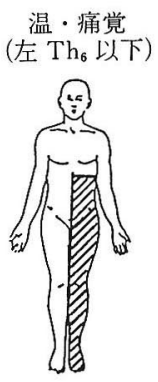

(a) 症例 1
触党

(左 $S_{1}$ 以下)

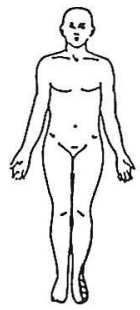

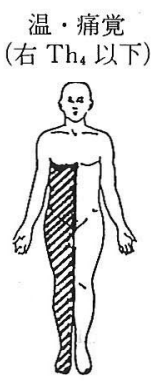

触党 (右 $\mathrm{Th}_{4}$ 以下)

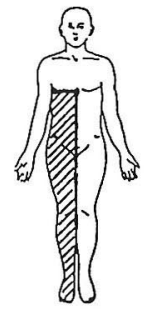

(b) 症例 2

図 1 知賞障害

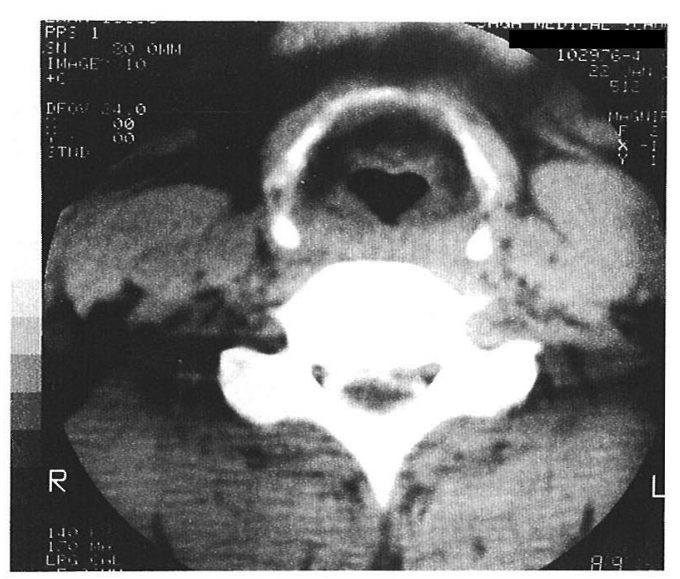

図 2 CTM にて $\mathrm{C}_{5-6}$ 椎間板高位にて硬膜管の前方 よりの圧迫所見を認めた。

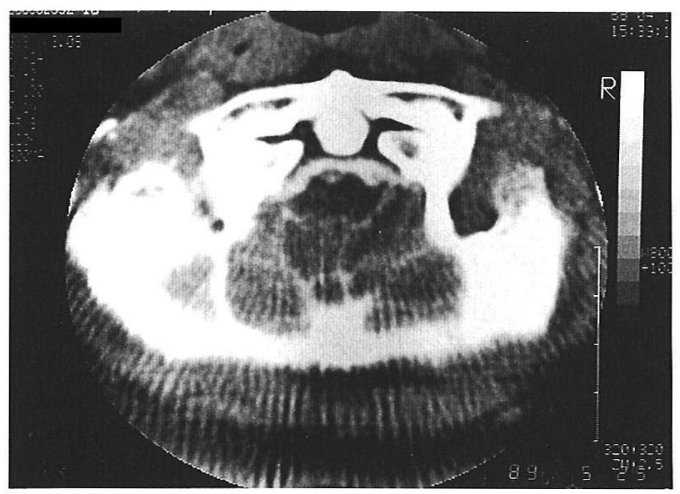

図3 CTM にて C 2 高位まで下降した小脳扁桃を 認めた.
知覚障害を認めた (図 1 (a)). 左下肢片脚起立がやや 不安定であったが, 歩行は正常であった.

腱反射は, 上肢正常であったが, 両側共にWartenberg 反射陽性で, 下肢は膝蓋腱反射, アキレス腱反射 共に両側で充進しており，Babinski 反射が両側で陽性， ankle clonus が両側で陽性であった.

脳背髄液検査では，異常を認めなかった。

顼椎 $\mathrm{X}$ 線所見では， $\mathrm{C}_{5-6}$ 椎間板腔に軽度の狭小化を 認めたが, 胸椎部には異常所見を認めなかった. 胸髄 症を疑いミエログラフィ一検査を行なったが, 胸椎部 には異常を認めなかった。頚椎部では $\mathrm{C}_{5-5}$ 椎間板高 位に一致して, 造影剤の通過障害が認められ, 前方よ りの造影剤の圧排所見を認めた. CT ミエロにて前方 右側より硬膜管を圧迫する骨棘および前方左側より硬 膜管を圧迫する軟部陰影を認め, MRI で $\mathrm{C}_{5-6}$ 椎間板 のヘルニアの確認した（図2）.

以上の所見より頚椎症性脊髄症と確定診断し保存療 法として, Glisson 率引などにて症状の軽快を認めた.

症例 $2: 38$ 才女性

主訴：右下肢じんじん感, 疼痛, 脱力感

現病歴：昭和60年 4 月頃より, 右下肢じんじん感, 疼痛, 脱力感が出現し近医にて腰椎椎間板へルニアと 診断され, 入院し保存療法にて症状軽快した. 昭和 62 年 4 月頃, 両澒部より肩へかけての疼痛, 右下肢痛出現 した．昭和62年 8 月頃より，右下肢しびれ感も自覚す るようになり, 症状は徐々に増悪した。

昭和 63 年 4 月 1 日, 当科受診し，5月12日大院した。 既往歴・家族歴：特記すべきこと無し.

大院時理学的所見：脳神経系では両側に左方向への 眼振を認め, 頝椎部に, 右回旋時に後頚部痛, $\mathrm{C}_{5},{ }_{6}$ 棘 
突起に圧痛を認めた，両上肢には明らかな知党, 運動 障害は認めなかった。右体幹より右下肢にかけて知覚 障害を認めた (図 1 (b ) ). 両側腸腰筋以下に軽度の筋 力低下を認め, 歩行は右痓性歩行であり, Romberg sign が陽性であった．腱反射は，上肢では両側とも軽 度光進しており，下肢では著明な元進を認めた。両上 肢にWartenberg 反射陽性，両下肢に Babinski 反射 陽性であった. patella clonus が偽陽性, ankle clonus が陽性であった，上肢の小脳性運動失調は，認められ なかったが, 下肢ではかかと膝試験が右不可, 左拙劣 であった.

脳脊髄液検査では，異常を認めなかった。

顼椎 $\mathrm{X}$ 線所見では，上位頚椎で蓨柱管前後径の拡大 を認めたが，胸椎部には異常所見を認めなかった．頝 肩腕症候群と胸随症の合併を疑い，ミエログラフィー
を行なったが, 胸椎部には異常を認めず, 頝椎部にも 明らかな通過障害は認めなかった。しかし， CT ミエロ で小脳扁桃は， $\mathrm{C}_{2}$ レベルまで下降し，後方より上位䅡 髄を圧迫しており，MRIでも同様の所見を確認した (図 3 ).

以上の所見より Arnold-Chiari 奇形と確定診断し, 下降した小脳扁桃による圧迫を除去する目的にて, $\mathrm{C}_{1.2}$ の椎弓切除術を行なった。 術後, 症状は著明に 改善した.

\section{2. 考察}

今回, 我々が経験したような下肢の知賞障害を主症 状として発症した頚椎疾患の報告例は少なく，むしろ， 本疾患では下肢の知覚障害は, 最も遅れて発現してく るとの報告もある゙．－一般には頌髄部に主病変を有する

表 1 今釜例 (1980) と自験例との比較

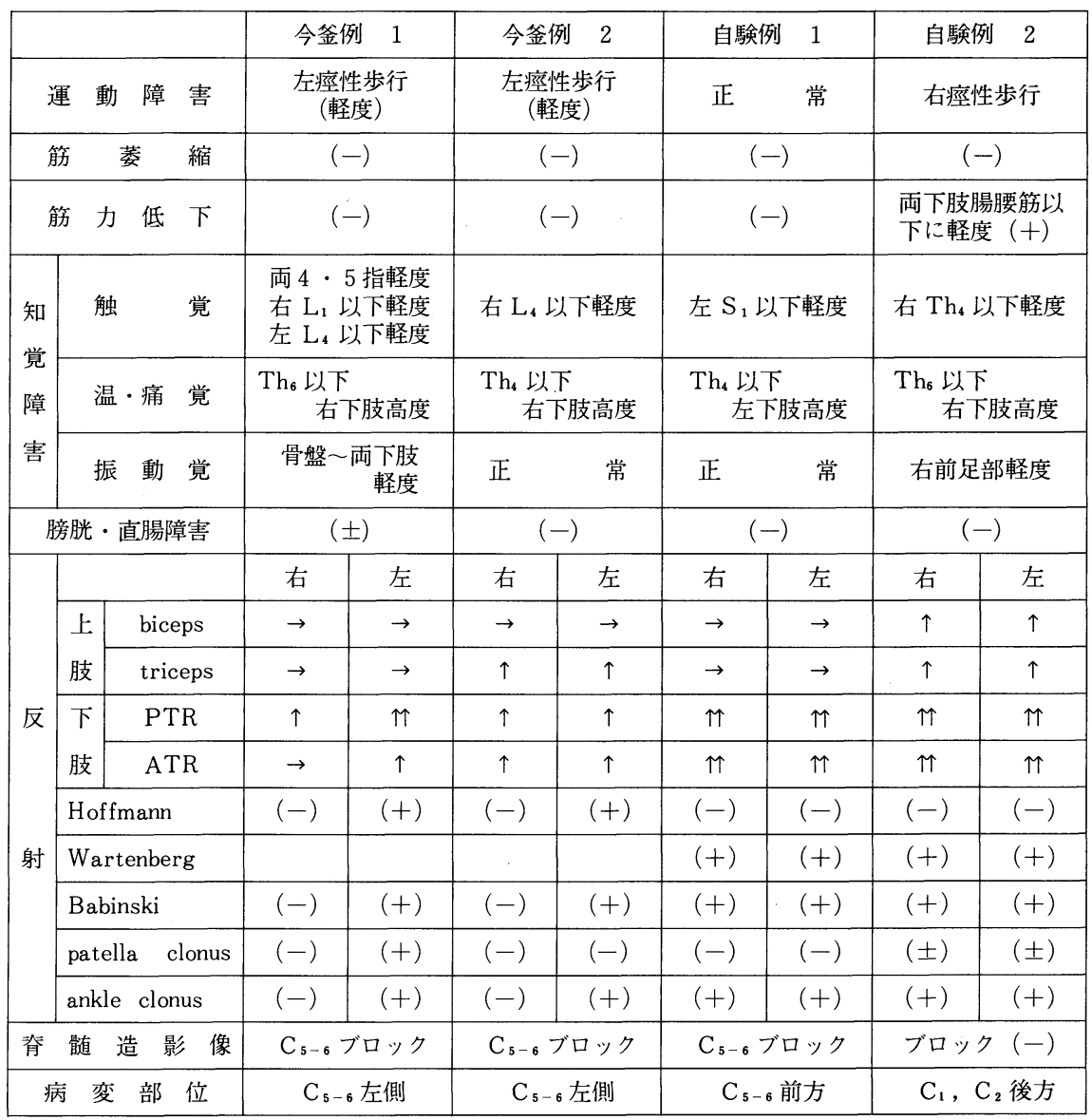


場合，何らかの上肢症状を主症状とすることが多い. 今釜ら $(1980)^{3)}$ が，下肢症状を主症状とした頚椎椎間 板へルニアの 2 例を報告しているが，これと今回の症 例を比較してみると類似点の多いのに気が付く．しか し, 今回の症例では, 今鉒らの 2 例と異なり知覚解離 は認められていない（表 1 ).

今回症例について頝髄部横断面の解剖を考えた場合, その障害部位は, 症例 1 では, 両側皮質春髄路の外側 部, 右背髄視床路の外側部, 左後索の内側部と考えら れ, 症例 2 では, 両側皮質资髄路の外側部より内側部 にかけて, 左春髄視床路の外側部より内側部にかけて, 右後索の内側部より外側部にかけてと推測され, 症例 1 よりも障害部は広範囲に及んでいる（図 4 ）。いずれに せよ2 例とも long-tract において, 下肢への繊維が 下降する, あるいは, 下肢からの繊維が上行する経路 である背髄外側からの障害が主で, 灰白質の障害は, 極めて少ないと思われる. これらは, 服部の病型分類 ${ }^{1}$ のいずれにもあてはまらない.

このような, 病態が生じた機序については種々の原 因が考えられる. 小野ら5)によれば，圧迫性资髄症の 場合, 白質の変性の度合いに比べると灰白質の変性は 一般に軽く, 白質の中でも側索の変性が最も強いと述 ベている. 同様のことは, 鶴海 $5^{6)}$, 服部ら ${ }^{1)}$, 廣島 $5^{21}$ の報告の中にも見受けられる.このことは, 今回の症

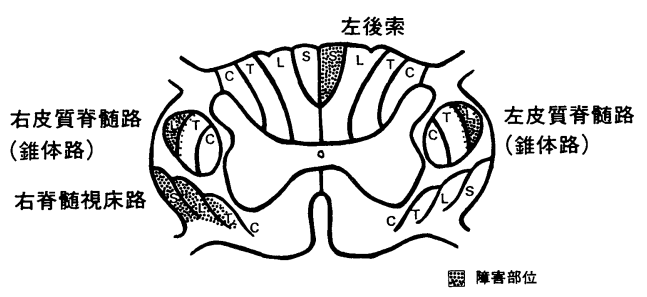

症例 1

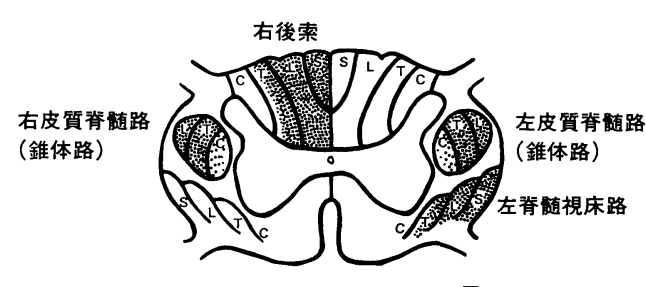

国障寒部位

症例 2
例の背髄横断面での解剖を考えた場合に推測される障 害部位に一致しているといえる. しかし, 以上の報告 に共通していることは, 頚髄症の場合, やはり上肢に 症状が初発することが多いということである. 今回の ように背髄外側部の障害により下肢症状が初発するこ とは少なく, 明確にはその理由について説明し得えな い. 耠髄の直接の圧迫のほか, それにより生じる応力に よる循環障害などもその一因となっていると思われる.

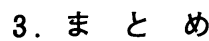

今回我々は, 初発時に胸髄症を疑わせた頚椎疾患 2 例 を経験した。 2 症例ともに体幹より片側下肢にかけて の知覚障害を主症状とし下肢腱反射の元進を認め, 最 初胸髄症を疑ったが, 精査の結果, 頚髄部に主病変が 認められた.

今釜らの報告した 2 症例と比較したところ, 多くの 共通点が認められた.

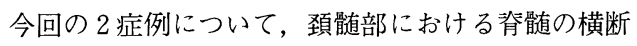
面の解剖を考えると, 灰白質の障害がほとんど無く, 主として, long-tractである皮質脊髄路 (錐体路)・ 春髄視床路外側の障害が中心となり, これに後索内側 の障害が一部加わり，下肢に症状が強く出現してきた ものと思われた。

\section{参 考 文 献}

1）服部 奨ほか：頚部背椎症性ミエロパチーの病態と 病型. 臨床整形外科, $10: 990-998,1975$.

2）廣島和夫ほか：慢性圧迫性脊髄症の病理組織変化に ついて. 日獨医報, 30:510-520, 1985.

3）今鉒哲男ほか：胸椎部ミエロパチーを疑わしめた䅡 椎椎間板へルニアの 2 例. 整形外科と災害外科, 29 : 269-272, 1980.

4）岡本吉正ほか：頚椎骨軟骨症による慢性脊骨道症の神 経症状. 中部整災, $8: 117-119,1965$.

5）小野啓郎：圧迫性脊髄症の臨床と病理. 日整会誌, $60: 103-118,1986$.

6）鶴海宽治ほか：頝部宵椎骨軟骨症の脊髄症状と診断. 整形外科, $13: 898-905,1962$.

\section{質 問総合せき損センター 芝 啓一郎}

下肢㽷性麻痺を主症状とし, 画像上, 頚椎と胸椎部 の両者に同程度の所見を得た場合は，主病態の診断は どのように考えますか.

図 4 尙髄横断面における障害部位 
解 答佐賀医科大学 堤 幸彦部を考えます。日常診療の中でそのような症例の頻度 両者に病変がある場合には, 下肢の㾏性麻痺のみで は非常に少ないと思われます。

上肢に症状がなければ，やはり責任病巣としては胸髄 